\title{
The LOSC Framework for Maritime Jurisdiction and Enforcement 30 Years On
}

\author{
Tim Stephens \\ Associate Professor, Co-Director, Sydney Centre for International Law, Faculty of Law, \\ University of Sydney, Sydney, Australia
}

Donald R. Rothwell

Professor, ANU College of Law, Australian National University, Canberra, ACT, Australia

\begin{abstract}
Rules of jurisdiction and immunity are central to public international law, and equally vital to the United Nations Convention on the Law of the Sea (LOSC). The LOSC established an extensive framework to regulate legislative and enforcement jurisdiction over ocean space; one that has proven to be remarkably durable, despite lingering uncertainties in the compromise reached between coastal and maritime states. State practice diverging from the LOSC's jurisdictional scheme has been isolated and infrequent, and the scheme has been strengthened and elaborated by regional and global treaties addressing contemporary oceans governance challenges, especially in the arenas of pollution control and fisheries management. As the LOSC turns thirty, a key challenge will be keeping in check the designs of coastal states over adjacent maritime space as they look seawards to address pressing concerns of resource, food, energy and environmental security.
\end{abstract}

\section{Keywords}

law of the sea; United Nations Convention on the Law of the Sea (LOSC); jurisdiction; enforcement

\section{Introduction}

Rules of state jurisdiction and immunity are critically important in bringing stability and order to international relations, ${ }^{1}$ as confirmed by the 2012 decision of the International Court of Justice in Jurisdictional Immunities of the State. ${ }^{2}$ These objectives are of equal importance to the law of the sea, the history of which may be narrated as a search for coherent rules to regulate the

1 Bruno Simma and Andreas Th. Müller, 'Exercise and Limits of Jurisdiction' in James Crawford and Martti Koskenniemi (eds), The Cambridge Companion to International Law (Cambridge University Press, Cambridge 2012) at 134.

2 [2012] ICJ Rep, in press. 
projection of state authority over the oceans. While the immunity attaching to foreign warships has enjoyed longstanding recognition, ${ }^{3}$ rules of maritime jurisdiction and enforcement have taken a lengthy and circuitous route to codification as more expansive and complex maritime zones have been asserted and accepted by the international community.

The 1982 United Nations Convention on the Law of the Sea ${ }^{4}$ (LOSC) grappled with the development of multiple maritime zones and set out an extensive framework to regulate the exercise of legislative and enforcement jurisdiction over ocean space. As is also characteristic of many other aspects of the LOSC, its jurisdictional rules embody an imperfect compromise between competing interests, and as a result are beset by several ambiguities. As Shearer observed in 1986, "there is no one theory of jurisdiction that underlies the various powers and competences accorded to States" under the LOSC, and various elements, including "territorial sovereignty, nationality, and protective and universal principles of jurisdiction... are intertwined with special functionally-based State competences". ${ }^{5}$

Thirty years on, and despite their imperfections, the jurisdictional rules of the LOSC have proven remarkably durable, with the amount of state practice diverging from them comparatively limited. ${ }^{6} \mathrm{~A}$ hallmark of the LOSC era has been the expansion of the law of the sea framework via additional instruments, such as the 1995 Fish Stocks Agreement (FSA), ${ }^{7}$ and complementary global and regional treaties. These have elaborated upon the LOSC's jurisdictional regime, most particularly with respect to fisheries and marine pollution, where coastal and port state jurisdiction has become particularly important. This article reviews these issues by reflecting upon 30 years of the LOSC. In doing so, we acknowledge and pay tribute to the pioneering work of the late Jon Van Dyke in charting the evolution of the LOSC's jurisdictional rules, especially as they relate to environmental protection. ${ }^{8}$

\footnotetext{
3 See, e.g., The Schooner Exchange v. M'Faddon, 11 U.S. 116 (1812).

41833 UNTS 397.

5 Ivan Shearer, 'Problems of Jurisdiction and Law Enforcement Against Delinquent Vessels' (1986) 35 International and Comparative Law Quarterly 320, 343.

${ }^{6}$ Robin R. Churchill, 'The Impact of State Practice on the Jurisdictional Framework Contained in the LOS Convention' in Alex G Oude Elferink (ed), Stability and Change in the Law of the Sea: The Role of the LOS Convention (Leiden, Martinus Nijhoff, 2005) at 91.

7 Agreement for the Implementation of the Provisions of the United Nations Convention on the Law of the Sea of 10 December 1982 Relating to the Conservation and Management of Straddling Fish Stocks and Highly Migratory Fish Stocks, 2167 UNTS 88.

8 See, among many others, Jon M. Van Dyke, 'The Disappearing Right to Navigational Freedom in the Exclusive Economic Zone' (2005) 29 Marine Policy 107; Jon Van Dyke, 'Military Ships and Planes Operating in the Exclusive Economic Zone of Another Country' (2004) 28
} 


\section{Coastal State Jurisdiction}

The LOSC not only set out jurisdictional rules for those maritime zones already recognised by treaty and customary international law (the territorial sea, contiguous zone, continental shelf and the high seas) but also fashioned a jurisdictional system for entirely new maritime zones (the exclusive economic zone (EEZ), archipelagic waters and the deep seabed).

The LOSC acknowledges the sovereignty of coastal states in the territorial sea, ${ }^{9}$ although subject to significant limitation by way of the innocent passage regime. ${ }^{10}$ In the post-9/11 world where national security is of utmost concern, the presence of foreign entities within a state's territorial space under an effective regime of deemed consent could be problematic. While there is some mixed coastal state practice regarding respect for innocent passage, this has tended to be driven less by concerns over the activities of non-state actors than over those of traditional state actors. For example, controversy has flared from time to time over whether warships and ships carrying hazardous cargo, such as nuclear waste, may lawfully exercise innocent passage. While the LOSC contemplates innocent passage by both categories of vessel, ${ }^{11}$ there has been some accumulation of divergent state practice. Over 30 parties from the global South (notably including China) require prior notification ${ }^{12}$ or prior authorisation ${ }^{13}$ before warships may enter the territorial sea. Fewer states have sought to impose such requirements for ships with hazardous cargo, and again the practice is clustered among developing states, with some exceptions (such as Canada and Portugal). There has been no acquiescence in these assertions of jurisdiction by the maritime powers in the North, with the United States and several parties to the LOSC registering their protest. ${ }^{14}$ As such it is not possible to argue that there has been subsequent practice that shifts the agreed interpretation of the LOSC, ${ }^{15}$ let alone which creates new customary

Marine Policy 29, Jon Van Dyke, 'The Legal Regime Governing Sea Transport of Ultrahazardous Radioactive Materials' (2002) 23 ODIL 77.

9 LOSC, Art. 2.

${ }^{10}$ LOSC, Arts. 17-26.

${ }^{11}$ For ships carrying dangerous substances this is made clear by Art. 23, and for warships it is implicit, particularly from Art. 20.

${ }_{12}$ Churchill, supra note 6, at 113, identifies 12 states, to which Slovenia may also be added (Maritime Code 2001).

${ }_{13}$ Churchill, ibid., identifies 20 states, to which can now be added Vanuatu (Maritime Zones Act, No. 06 of 2010).

${ }_{14}$ Ibid., at 114.

15 See Vienna Convention on the Law of the Treaties, 1155 UNTS 332, Art. 31(3). 
norms that would override these fundamental LOSC provisions regarding the territorial sea.

Coastal state jurisdiction in international straits and the rights of newly recognised archipelagic states in archipelagic sea-lanes have, on the other hand, been more contentious, and reminiscent of a decisive moment in the development of the law of the sea: the Corfu Channel case. ${ }^{16} \mathrm{~A}$ feature of the LOSC regime and its balancing of littoral state jurisdiction and enforcement against the rights of user states has been the role of the International Maritime Organization (IMO) where debates over the security jurisdiction (both national and environmental) of coastal states have played out. For example, in 2006 Australia implemented a system of compulsory pilotage in the Torres Strait. ${ }^{17}$ This measure, taken in the wake of IMO endorsement of a joint Australian/Papua New Guinea-sponsored initiative based on environmental grounds and safety of shipping, was subsequently watered down following protest from several states, including the United States and Singapore, that the scheme was inconsistent with the LOSC transit passage regime. Likewise, the designs of the two largest archipelagic states, Indonesia and the Philippines, to set archipelagic sea-lanes of their choice have been kept in check by the maritime powers through the IMO. If anything, the asserted jurisdiction of these states over their archipelagic waters has been retreating rather than advancing during the LOSC era.

The 'specific legal regime' of the EEZ remains an innovation of the LOSC that rapidly found acceptance in customary international law, notwithstanding the elaborate provisions in Part V balancing the sovereign rights and jurisdiction of the coastal state, with ongoing freedoms by all states within the zone, especially with respect to navigation and overflight. The EEZ's complex jurisdictional regime has attracted a great deal of attention since 1982, not only through state practice, but also in disputes before international courts and tribunals.

The International Tribunal for the Law of the Sea (ITLOS) in $M / V$ Saiga (No 2) ${ }^{18}$ brought some clarity to coastal state prescriptive jurisdiction in the EEZ, finding that customs laws could not be applied to, or enforced in, the EEZ. Rather, the Tribunal indicated that coastal states may only legislate with respect to the specific matters set out in Article 56 (living and non-living resources, artificial islands, installations and structures, marine scientific research, and environmental protection). The $M / V$ Saiga case is also one of a

16 Corfu Channel (United Kingdom v Albania) [1949] ICJ Rep 4.

17 Sam Bateman and Michael White, 'Compulsory Pilotage in the Torres Strait: Overcoming Unacceptable Risks to a Sensitive Marine Environment' (2009) 40 ODIL 184.

18 (1999) 120 ILR 143. 
number of ITLOS decisions concerning coastal state EEZ enforcement jurisdiction which have often raised questions relating to the prompt release of vessels arrested for fisheries offences. These cases have raised doubts whether the fisheries jurisdiction of coastal states in their EEZ is adequate to deal with illegal, unreported and unregulated (IUU) fishing, and prompted some creative legislative responses to circumvent the prohibition on corporal punishment of arrested vessel crews. Generally, however, ITLOS has sought to constrain acts of excessive coastal state jurisdiction within the EEZ. ${ }^{19}$

Prescriptive coastal state jurisdiction over EEZ marine pollution has expanded greatly since the LOSC was concluded, as a result of initiatives within the IMO to address ship-sourced pollution and dumping. While these have effectively thickened coastal state marine environmental jurisdiction in the EEZ, as the LOSC incorporates IMO standards by reference, ${ }^{20}$ coastal state enforcement jurisdiction is contained within the limits provided for in Article 220. On occasion some states have adopted unilateral measures (such as the ban on single-hulled oil tankers by France, Spain and Portugal in the wake of the 2002 Prestige disaster), but these moves have often prompted the IMO to strengthen its rules rather than a cascade of practice inconsistent with the LOSC. Several South Pacific and Latin American states have also sought to exclude vessels carrying nuclear waste from their EEZs, though to date these remain isolated incidents.

One major unresolved flashpoint between some coastal states and naval powers in the EEZ has been whether coastal states may exercise security jurisdiction, particularly to prohibit or limit military activities carried out by foreign states within the EEZ. While Articles 56 and 58 contain reciprocal 'due regard' provisions reflecting the differential rights and interests of the coastal state and other states within the EEZ, the LOSC does not make clear whether naval manoeuvres and exercises, including weapons testing, surveillance, or survey activities, are permissible in the EEZ as high seas freedoms. The matter is instead left for resolution through one of the most ambiguous provisions of the LOSC, Article 59, which calls for conflict between coastal and other states over jurisdiction in the EEZ to be "resolved on the basis of equity". ${ }^{21}$ The 2009 USNS Impeccable incident between China and the United States in the South China Sea over contested survey activities within China's EEZ highlighted the lines blurred in oceanographic surveys that may be conducted for civil, or military purposes, or both. The only way forward on the issue is a compromise position between blanket prohibition and unfettered licence:

19 These issues were highlighted in Volga (Russian Federation v. Australia) (2003) 42 ILM 159.

20 See, e.g., Art. 211(5).

21 Shearer, supra note 5 at 334. 
one that would allow military activities that do not manifestly prejudice coastal state security, such as the use of live weapons. ${ }^{22}$

\section{Flag State Jurisdiction}

High seas jurisdictional rules under treaty and customary international law pre-dated the LOSC, and the Convention reaffirmed these provisions rather than establishing new rules (with the curious exception of the right of visit for ships engaged in unauthorised radio broadcasting). An important exception was the allowance made for the interaction of high seas jurisdiction with coastal state EEZ jurisdiction where the two zones interact between 12 and 200 nautical miles. On the high seas the LOSC reaffirmed the exclusivity of flag state jurisdiction as the pre-eminent jurisdictional rule, ${ }^{23}$ a privilege counterbalanced by the duties of flag states to exercise effective control over ships flying their flag. ${ }^{24}$ However, this trade-off has always been unsatisfactory, as the genuine link requirement for the nationality of ships is a minimal one, ${ }^{25}$ and flags of convenience have prospered and remain a challenge to effective oceans governance both for the law of the sea and maritime law.

With respect to the exercise of jurisdiction on the high seas, there has been no serious argument that the right of visit extends beyond the recognised exceptions to exclusive flag state jurisdiction in Article 110 (piracy, slave trading, stateless ships, and unauthorised radio broadcasting) and the right of hot pursuit under Article 111. One potential challenge to the LOSC legal regime was the United States-led Proliferation Security Initiative (PSI) adopted in the wake of post-9/11 concerns over non-state actors and the proliferation of weapons of mass destruction. Yet the PSI, which is essentially a counterterrorism response that also extended to state sponsors and supporters of terrorism, has not to date raised significant flag state concerns over excessive exercise of high seas interdiction rights.

The long-standing high seas right of hot pursuit, now of even greater significance given a coastal state's multiple maritime zones, has raised some practical issues that have not been fully resolved, such as whether the requirement that the pursuit of a fleeing vessel be continuous is met by radar tracking. In

22 Natalie Klein, Maritime Security and the Law of the Sea (Oxford University Press, Oxford, 2011) at 49.

${ }^{23}$ LOSC, Art. 92(1).

${ }^{24}$ LOSC, Art. 94.

${ }_{25} M / V$ Saiga (No 2) (Saint Vincent and the Grenadines v. Guinea) (admissibility and merits) (1999) (1999) 120 ILR 143, [83]. 
assessing aspects of hot pursuit in $M / V$ Saiga (No 2), ITLOS also clarified the extent of force that can be lawfully used when exercising that right. ${ }^{26}$ The use of force at sea in a non-armed conflict situation has also gained additional contemporary relevance as a result of counter-piracy operations over the past decade, particularly in the Indian Ocean. The limited reach of the classical definition of piracy embodied in Article 101 (with, among other things, the 'two vessels' condition) has been largely remedied through the 1988 Convention for the Suppression of Unlawful Acts Against the Safety of Maritime Navigation Convention, ${ }^{27}$ as amended by a 2005 Protocol, in addition to specific United Nations Security Council action. ${ }^{28}$

Despite highly elevated security concerns in the contemporary maritime arena, there have been few violations of flag state jurisdiction. Instead states have sought through consensual arrangements to confer reciprocal rights of interdiction in relation to drug trafficking and fisheries. ${ }^{29}$ The FSA, negotiated in 1995 against the backdrop of Canada's 1993 high seas arrest of the Spanishflagged Estai, ${ }^{30}$ illustrated a more assertive and cooperative approach towards high seas jurisdiction between coastal, flag and port states. The FSA not only provides an improved framework for the management of straddling and highly migratory fish stocks, but through a system of inspection it also allows members of regional fisheries management organisations (RFMOs) to board and inspect vessels flying the flag of other RFMO parties. There is also increasing focus on governance principles for areas beyond national jurisdiction and a dawning realisation that these areas may be managed via the LOSC and other established rules of international law rather than by a radical reapportionment of jurisdiction. ${ }^{31}$ The best example of this is the 2011 Advisory Opinion of the Seabed Disputes Chamber of ITLOS on the Responsibilities and Obligations of States Sponsoring Persons and Entities with Respect to Activities in the Area, ${ }^{32}$ which found that states sponsoring deep seabed mining are bound by demanding obligations to ensure that persons under their jurisdiction comply with

26 (1999) 120 ILR 143, [155] ("the use of force must be avoided as far as possible and, where force is unavoidable, it must not go beyond what is reasonable and necessary in the circumstances.")

271678 UNTS 221.

${ }^{28}$ Douglas Guilfoyle, 'The Legal Challenges in Fighting Piracy' in Bibi van Ginkel and Franspaul Van Der Putten (eds), The International Response to Somali Piracy (Martinus Nijhoff, Leiden, 2011) at 127.

29 Douglas Guilfoyle, Shipping Interdiction and the Law of the Sea (Cambridge University Press, Cambridge, 2009) at 19-20.

30 Fisheries Jurisdiction (Spain v. Canada) [1998] ICJ Rep 432.

31 Alex G. Oude Elferink, 'Governance Principles for Areas Beyond National Jurisdiction' (2012) 27 IJMCL 205.

32 (2011) 50 ILM 455. 
the LOSC and the mining code promulgated by the International Seabed Authority. ${ }^{33}$

\section{Port State Jurisdiction}

One of the more significant achievements of the LOSC in relation to jurisdiction was the extension of port state control. While it has always been accepted that port states may exercise jurisdiction over foreign vessels, which do not otherwise enjoy sovereign immunity, when voluntarily in port, the LOSC gave jurisdictional powers to port states in relation to certain activities beyond the port, namely pollution caused in any maritime zone. These provisions, found in Part XII of the Convention, have now been expanded by additional IMO instruments focussing on marine environmental protection, and by the FSA and related RFMOs in the context of fisheries management and regulation. With additional support by regional and global instruments, such as the Paris Memorandum of Understanding on Port State Control and the 2009 FAO Agreement on State Measures to Prevent, Deter and Eliminate IUU Fishing, ${ }^{34}$ port state jurisdiction has emerged over the past 20 years as an effective replacement for (and not merely a supplement to) coastal and flag state jurisdiction. Like flag states, port states may assert a prescriptive and enforcement jurisdiction that is largely coincident, and with concerted cooperation by the world's major port states, unscrupulous operators are unable to escape tightening rules on environmental protection and maritime safety.

\section{Conclusion}

An ever-present feature of the modern law of the sea is balancing the rights and interests of coastal states with those of maritime states (although we hasten to note that as many states straddle the coastal state/maritime state division there is an inherent tendency towards accommodation of both sets of interests). Since the 1945 Truman Proclamation, the law of the sea has witnessed a remarkable expansion in coastal state sovereignty and jurisdiction beyond the shoreline. The LOSC brought certainty to the spatial extent of

33 David Freestone, 'Advisory Opinion of the Seabed Disputes Chamber of International Tribunal for the Law of the Sea on "Responsibilities and Obligations of States Sponsoring Persons and Entities with Respect to Activities in the Area"' (2011) 105 AJIL 755-760.

${ }_{34}$ Paris MOU: http://www.parismou.org; FAO Agreement, opened for signature 22 November 2009, not yet in force: http://www.fao.org. 
coastal state jurisdiction and to the jurisdictional capacities of port, coastal and flag states within the various maritime zones. Coastal state jurisdiction is now in the process of a new period of expansion. There is the LOSCsanctioned enlargement of jurisdiction through coastal state sovereign rights over newly proclaimed outer continental shelves beyond the 200-nauticalmile limit. There are also ongoing efforts to test the extent of traditional national security control over the coastal maritime domain. Over the next 30 years, there is little question that coastal states will look seawards to address even broader security imperatives, encompassing resource, food, energy and environmental security concerns. Since 1982 the LOSC has been effective in circumscribing excessive coastal state jurisdiction and, where maritime jurisdiction has expanded, this has occurred as a result of an orderly process at a regional or global level via multilateral institutions. In regulating the various competences of states over ocean space, the LOSC has stood the test of time, but ongoing vigilance will be necessary to maintain the Convention's jurisdictional equilibrium. 
